\title{
Retrospective Evaluation of Perinatal and Early Neonatal Outcomes in Infants of Migrant Mothers: A Case-Controlled Study
}

\author{
Göçmen Anne Bebeklerinde Perinatal ve Erken Dönem Neonatal Sonuçların \\ Retrospektif Değerlendirilmesi: Vaka-Kontrollü Çalışma
}

\author{
Ozgul BULUT $\odot$, Sibel SEVUK $\odot$, Nuran USTUN $\odot$, Sertac ARSLANOGLU $\odot$, Fahri OVALI $\odot$
}

Ethics Committee Approval: This study approved by the Istanbul Medeniyet University, Goztepe Training and Research Hospital, Clinical Studies Ethic Committee, 28 August 2019, 2019/0332. Conflict of interest: One of the authors of this article is an Editorial Board Member of this journal and was excluded from all evaluation steps. The other authors declare that they have no conflict of interest.

Funding: None.

Informed Consent: Not Applicable.
Cite as: Bulut O, Sevuk S, Ustun N, Arslanoglu S, Ovali F. Retrospective evaluation of perinatal and early neonatal outcomes in infants of migrant mothers: A case-controlled study. Medeniyet Med J. 2019;34:368-73.

\begin{abstract}
Objective: To investigate the incidence of perinatal features and neonatal morbidities in migrant mothers in comparison with native Turkish mothers.

Method: A retrospective analysis was conducted using the medical records of 89 infants born to Syrian immigrants and 89 infants born to native Turkish mothers who were consecutively admitted to the neonatal intensive care unit of our hospital between 2015 and 2019. Statistical analyses were used to compare demographic data and perinatal and neonatal outcomes between the two groups.

Results: Compared to Turkish mothers, Syrian mothers were significantly younger and adolescent pregnancy rate was significantly higher $(p<0.01)$. The rates of multiple pregnancy, consanguineous marriage, and prolonged premature membrane rupture were also significantly higher in Syrian mothers $(p<0.05)$. The incidence rates of congenital anomalies, respiratory distress syndrome, transient tachypnea of newborn pneumonia/bronchiolitis, sepsis, jaundice, and feeding problems were the same for infants born to Syrian and Turkish mothers $(p>0.05)$. In addition, the two groups did not differ with respect to gestational week at birth, birth weight, sex, types of delivery, Apgar score, duration of hospital stay, and incidence of infant mortality ( $p>0.05)$.

Conclusion: The immigrant status negatively affects perinatal and neonatal outcomes. However, the incidence rates of infant mortality and neonatal morbidity did not differ between infants born to Syrian and those born to Turkish mothers. This may be due to the recent improvements in the of overall health status of migrant women or of those migrants living in Turkey being able to have access to increased prenatal and postnatal period policies of mother-child health services which have been successfully implemented.
\end{abstract}

Keywords: Immigrant, neonatal outcomes, Syrian refugees

öz

Amac: Göcmen anne bebeklerinde perinatal özelliklerin ve neonatal morbiditelerin görülme sıkIığının araştırılması, Türk anne bebekleriyle karşıllaştırılması.

Yöntem: Hastanemizde 2015-2019 yılları arasında yenidoğan yoğun bakım ünitesine yatan 89 Suriyeli anne bebekleri ile aynı dönemde ardısılk yatan 89 Türk anne bebeklerinin verileri retrospektif olarak dosya kayıtlarından elde edildi. Iki grup arasında demografik data, perinatal ve neonatal sonuçlar karşılaştırmak için istatistiksel analiz yapıldı.

Bulgular: Suriyeli annelerin yaş ortalaması anlamlı olarak daha düşük, adölesan gebelik oranı anlamlı olarak daha yüksekti $(p<0,01)$. Suriyeli annelerde çoğul gebelik, akraba evliliği ve uzamıs erken membran rüptürü görülme oranı da Türk annelere göre istatistiksel olarak anlamlı derecede daha yüksek saptandı $(p<0,05)$. Konjenital anomaliler, respiratuvar distress sendromu, yenidoğanın geçici takipnesi pnömoni/bronşiolit, sepsis, sarılık ve beslenme problemi insidansı Suriyeli ve Türk annelerden doğan bebeklerde benzerdi. Bunun yanında, gestasyon haftası, doğum ağırlığı, cinsiyet, doğum şekli, düşük Apgar skoru, hastanede yatıss süresi ve mortalite görülme sıklığı açısından Suriyeli anne bebekleri ile Türk anne bebekleri arasında anlamlı farklılı görülmedi $(p>0,05)$.

Sonuc: Göçmen statüsü perinatal ve neonatal sonuçları olumsuz etkileyen bir faktördür. Bununla birlikte, Suriyeli anne bebeklerinde mortalite ve neonatal morbidite görülme sıklığı Türk anne bebeklerine göre belirgin bir farklılık göstermemektedir. Bu, son dönemde göçmenlerin sağlığının genel bir iyileşmesinden veya Türkiye'de yaşayan göcmen kadınların doğum öncesi ve sonrası dönemlerinde anne-çocuk sağlığı hizmetlerine erişebilirliği artıran politikaların başarılı bir şekilde uygulanmasından kaynaklanıyor olabilir.

Anahtar kelimeler: Göçmen, neonatal sonuçlar, Suriyeli mülteciler

(c) Copyright Istanbul Medeniyet University Faculty of Medicine. This journal is published by Logos Medical Publishing.

Licenced by Creative Commons Attribution-NonCommercial 4.0 International (CC BY-NC 4.0)
Received: 6 October 2019

Accepted: 9 November 2019 Online First: 26 December 2019

Corresponding Author: O. Bulut

ORCID: 0000-0001-9939-7375

Istanbul Medeniyet University

Goztepe Training and Research

Hospital, Department of Pediatrics,

Division of Neonatology, Istanbul, Turkey

ozgulbulut@yahoo.com

S. Sevuk

ORCID: 0000-0001-8023-8075

N. Ustun

ORCID: 0000-0003-1680-1825

S. Arslanoglu

ORCID: 0000-0002-1636-9991

F. Ovali

ORCID: 0000-0002-9717-313X

Istanbul Medeniyet University

Goztepe Training and Research

Hospital, Department of Pediatrics,

Division of Neonatology, Istanbul, Turkey 


\section{INTRODUCTION}

The immigrant population in Turkey is steadily increasing. Turkey represents a bridge between Asia and Europe, making it a major transit country and for many years it has been the centre of migration ${ }^{1}$. It has been the country for important transit stops and a place where people settle as informal workers, especially for those who want to migrate from Asian to European Countries. Whilst our country has mostly received immigration from Asian countries, Syrians constitute the largest immigrant population in recent years due to the war in Syria. According to the 2019 United Nations High Commissioner for Refugees (UNHCR) report, 3.6 million of the nearly 4 million immigrants living in Turkey have migrated from Syria ${ }^{2}$. In the past 8 years, approximately 400,000 Syrian mothers have given birth in Turkey ${ }^{2}$, creating an increased demand for neonatal healthcare. Minorities living among different local communities have been reported to have higher rates of preterm birth, asphyxia, congenital anomalies, stillbirths, puerperal infections, cesarean deliveries, gestational diabetes, perinatal mortality, and lower birthweights, and Apgar scores ${ }^{3-7}$. Other reports indicate that female immigrants, especially children and adolescents, were more commonly victims of traumatic events, which increases the risk of preterm births ${ }^{8}$. The aim of this study was to evaluate the perinatal characteristics of Syrian mothers and the incidence of neonatal morbidities in newborns in the neonatal intensive care unit (NICU).

\section{MATERIALS and METHODS}

This study was approved by the Istanbul Medeniyet University, Goztepe Training and Research Hospital, Clinical Studies Ethics Committee on August 28, 2019 with decision number: 2019/0332. Since the study was conducted retrospectively and the data was scanned from the patient files, an informed consent form was not obtained.
We retrospectively analyzed the NICU records of infants born to Syrian or native Turkish mothers between January 2015 and August 2019. Patients' demographic characteristics, early clinical features, and rates of hospitalization and mortality were evaluated. The following data were noted: gestational week at birth, birth weight, Apgar scores (skin color, heart rate, reflexes, muscle tone, respiration) at $1^{\text {st }}$ and $5^{\text {th }}$ minutes, sex, delivery mode, need for hospitalization, need for phototherapy for jaundice, congenital abnormalities, respiratory distress syndrome (RDS), transient tachypnea of the newborn (TTN), pneumonia/bronchiolitis, feeding problems, duration of stay, mortality, maternal age, consanguineous marriage, treatment with Assisted Reproductive Techniques (ART), gravidity, parity, multiple pregnancy, preeclampsia, incidence of $>18 \mathrm{~h}$ early membrane rupture (EMR) time, gestational diabetes status, and antenatal steroid use. Gestational age was calculated based on the date of last menstrual period and the Ballard scoring system. Infants with a birth weight less than the $10^{\text {th }}$ percentile were classified as small for gestational age (SGA), and pregnant women between 16-19 years of age were classified as adolescents. Patients that were referred from outside centers with missing data were excluded from the study.

\section{Statistical analysis}

The SPSS software (ver. 20; IBM Corporation, Armonk, NY, USA) was used for statistical analyses. Quantitative data were expressed as means \pm standard deviations, and categorical data were expressed as percentages. Pearson's chi-square test and the Mann-Whitney $U$ tests were used to identify differences between the groups. The cut-off value for statistical significance was set at 0.05 .

\section{RESULTS}

A total of 3.456 infants were admitted to our NICU between 2015 and 2019. Ninety-one infants (2.6\%) were born to Syrian mothers. Two of 
these infants were excluded because they were transferred from other centers with incomplete medical records. Therefore, a total of 178 newborns born to 89 Syrian and 89 Turkish mothers were included in the study. The demographic characteristics of Syrian and Turkish mothers are presented in Table 1 . Syrian mothers were younger than Turkish mothers $(25.6 \pm 6.5$ years vs $30.0 \pm 6.4$ years, $p<0.001$ ) and consisted of higher number of adolescents ( $24 \%$ vs $4.5 \%, \mathrm{p}<0.01$ ). Any intergroup differences as for gravidity, parity, antenatal steroid/ART usage, rate of caesarian

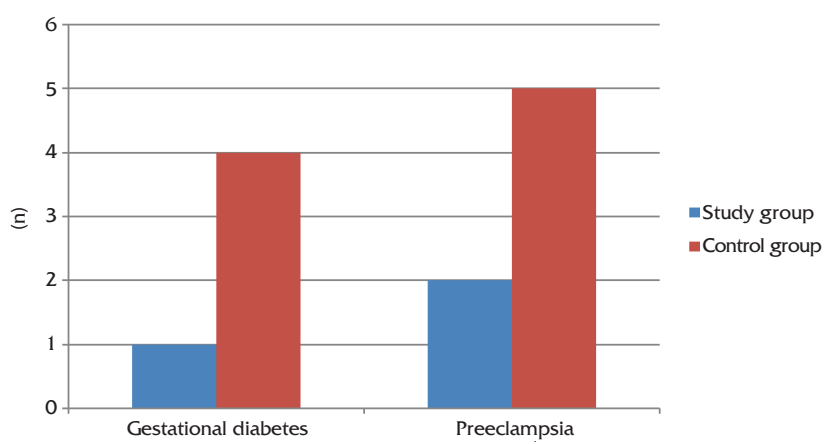

Figure 1. The rates of gestational diabtes and preeclampsia in the Syrian and Turkish mothers.

Table 1. Demographic characteristics of the Syrian and Turkish mothers.

\begin{tabular}{|c|c|c|c|}
\hline & $\begin{array}{l}\text { Study group } \\
(\mathbf{n}=\mathbf{8 9})\end{array}$ & $\begin{array}{l}\text { Control group } \\
(n=89)\end{array}$ & $\mathbf{p}$ \\
\hline Age (years), mean \pm SD & $25.6 \pm 6.5$ & $29.9 \pm 6.4$ & $<0.001$ \\
\hline Adolescent pregnancy(16-19 years), n (\%) & $21(24)$ & $4(4.5)$ & $<0.001$ \\
\hline Consanguineous marriage, $\mathrm{n}(\%)$ & $20(23)$ & $9(10)$ & 0.02 \\
\hline Cesarean delivery, n (\%) & $48(53.9)$ & $55(61.8)$ & 0.29 \\
\hline Gravidy, ort (min-max) & $2.32(0-9)$ & $2.54(1-6)$ & 0.12 \\
\hline Parity, ort (min-max) & $1.08(0-6)$ & $1.12(0-4)$ & 0.45 \\
\hline Multiple pregnancy, n (\%) & $11(12.4)$ & $2(2.2)$ & 0.01 \\
\hline Spontaneous, n (\%) & $9(10.1)$ & $0(0)$ & 0.002 \\
\hline Assisted reproductive therapy, n (\%) & $2(2.2)$ & $2(2.2)$ & 1 \\
\hline Assisted reproductive therapy, $\mathrm{n}(\%)$ & $3(3.4)$ & $2(2.2)$ & 0.99 \\
\hline Antenatal steroids, n (\%) & $10(11.2)$ & $6(6.7)$ & 0.30 \\
\hline Premature rupture of membranes, $\mathrm{n}(\%)$ & $12(13.5)$ & $4(4.5)$ & 0.04 \\
\hline Gestational diabetes, $\mathrm{n}(\%)$ & $1(1.1)$ & $4(4.5)$ & 0.37 \\
\hline Preeclampsia, $\mathrm{n}(\%)$ & $2(2.3)$ & $5(5.6)$ & 0.44 \\
\hline
\end{tabular}

SD: standart deviation, min-max: minimum-maximum

Tablo 2. Demographic and clinic characteristics of Syrian and Turkish newborn.

\begin{tabular}{|c|c|c|c|}
\hline & $\begin{array}{l}\text { Study group } \\
(\mathbf{n}=\mathbf{8 9})\end{array}$ & $\begin{array}{l}\text { Control group } \\
(n=89)\end{array}$ & $\mathbf{p}$ \\
\hline$\overline{\text { Gestational age (weeks, mean } \pm \text { SD) }}$ & $36.62 \pm 3.50$ & $36.37 \pm 3.65$ & 0.65 \\
\hline Birth weight (gram, mean \pm SD) & $2705 \pm 787$ & $2656 \pm 921$ & 0.71 \\
\hline Preterm, n (\%) & $51(41)$ & $56(45)$ & 0.52 \\
\hline Gender (male), n (\%) & $50(56)$ & $51(57)$ & 0.88 \\
\hline Small for gestational age, $\mathrm{n}(\%)$ & $1(0.8)$ & $1(0.8)$ & 1 \\
\hline Apgar minute 1 , mean $\pm S D$ & $6.0 \pm 1.7$ & $6.0 \pm 2.1$ & 0.74 \\
\hline Apgar minute 5 , mean \pm SD & $8.0 \pm 1.1$ & $8.0 \pm 1.5$ & 0.51 \\
\hline Congenital anomalies, n (\%) & $8(9)$ & $6(6.7)$ & 0.58 \\
\hline Transient tachypnea of newborn & $28(31.5)$ & $38(43)$ & 0.12 \\
\hline Respiratory distress syndrome, n (\%) & $11(12.4)$ & $12(13.5)$ & 0.82 \\
\hline Bronchopneumonia/Bronchiolitis, n (\%) & $4(4.5)$ & $1(1.1)$ & 0.37 \\
\hline Sepsis, $n(\%)$ & $5(4)$ & $8(6.5)$ & 0.87 \\
\hline Hyperbilirubinemia, n (\%) & $40(45)$ & $40(45)$ & 1 \\
\hline Neonatal mortality, n (\%) & $5(5.6)$ & $3(3.4)$ & 0.72 \\
\hline Duration of hospitalization (day), (min-max) & $14(1-131)$ & $18(2-177)$ & 0.39 \\
\hline
\end{tabular}

SD: standard deviation, min-max: minimum-maximum. ${ }^{*} p<0.05$ 
delivery were detected $(p>0.05)$. There was not a significant difference between the rates of gestational diabetes or preeclampsia between the two groups (Figure 1). Multiple pregnancy rates were higher in Syrian mothers (12.4\% vs 2.2\%, $\mathrm{p}<0.01$ ). With the exception of two ART cases, all multiple pregnancies were classified as spontaneous. The incidence rates of consanguineous marriage and premature rupture of membranes in Syrian mothers were significantly higher compared with Turkish mothers ( $23 \%$ vs $10 \%, \mathrm{p}<0.01 ; 13.5 \%$ vs $4.5 \%, \mathrm{p}<0.04$, respectively; Table 1 ). There were no differences in mean gestational week at birth, sex ratio, SGA, $1^{\text {st }}$ and $5^{\text {th }}$ minute Apgar scores, RDS, TTN, congenital abnormalities, need for hospitalization, need for phototherapy for jaundice, nutritional problems, sepsis, duration of hospital stay, incidence rates of morbidity, and mortality between infants born to Syrian mothers and infants born to Turkish mothers ( $p>0.05$; Table 2 ).

\section{DISCUSSION}

The Syrian civil war has driven millions of Syrians from their country into Turkey, which has considerably increased the number of Syrian women giving birth in Turkey. Studies have reported an increased prevalence of stillbirth, low birth weight, preterm birth, antenatal complications, and puerperal infection in women since the war as compared to the pre-war period ${ }^{9,10}$. Inconsistent antenatal follow-up, socio-economic factors, language problems, and difficulty in accessing health services may all contribute to the observed negative outcomes in migrant women ${ }^{5}$. In our study, the Syrian mothers were younger with higher number of adolescents and displayed increased rates of consanguineous marriage and early membrane rupture compared to Turkish mothers. Cantürk et al. ${ }^{11}$ reported that refugee women received inconsistent antenatal follow-up healthcare and exhibited higher rates of adolescent pregnancies, average parity, and anemia. Similarly, Demirci et al. ${ }^{12}$ reported that the average age, average hemoglobin level, and birth weights were lower among female Syrian refugees. Not only is safety a key concern for immigrant children but they also face challenges in assimilating into a new society. Many children and adolescents immigrate to other countries to protect themselves from common challenges such as early-age consanguineous marriages. Low birth weight and preterm labor complications occur more frequently in adolescent pregnancies ${ }^{13,14}$. Thus, it is possible that the high rate of PROM exhibited by our Syrian study participants may relate to the high rate of adolescent pregnancy within this group.

Previous reports showed higher cesarean birth rates in Turkish women compared with Syrians ${ }^{11,15}$. In addition, studies based in Lebanon and Jordan indicated that cesarean birth rates among Syrian refugees are higher compared with local populations ${ }^{16,17}$. In our study, caesarean birth rates were similar in both groups and were 10-15\% above the rates recommended by World Health Organization $^{18}$. The most common reason for cesarean birth in Turkish women was history of cesarean section. The indication for cesarean section in Syrian migrants could not be determined due to the lack of available medical history. Sorby et al. ${ }^{19}$ reported that cesarean rates among migrants increased with duration of time spent in the host country.

Demirci et al. ${ }^{12}$ reported that gestational diabetes and preeclampsia were more common in Turkish pregnant women than in Syrian pregnant women and attributed this to the fact that Turkish mothers were older and had better access to healthcare. Göngör et al. ${ }^{15}$ reported a higher rate of gestational diabetes in pregnant Turkish women but could not find any difference in the rate of preeclampsia. By contrast, Kandasamy et al. ${ }^{20}$ found that the incidence rates of gestational diabetes and preeclampsia were the same for refugee and control groups. In our study, incidence rates of gestational diabetes and preeclampsia were similar between Syrian and Turkish subjects. This finding suggests that antenatal healthcare has improved for preg- 
nant Syrian women residing in Turkey. Therefore, the number of pregnant Syrian women diagnosed with gestational diabetes and preeclampsia increased compared to previous years.

Immigrant status was shown to be a risk factor for preterm birth, low birth weight, low Apgar score, asphyxia, congenital anomaly, and stillbirth ${ }^{11,21-}$ 23. However, other studies suggested that immigration was a protective factor for certain perinatal outcomes. For example, the risk of preterm birth was reported to be lower in Somali mothers living in four European countries, Australia, and Canada ${ }^{24}$. Similarly, immigrant infants were associated with an increased rate of premature birth and low birth weight compared with native Spanish infants ${ }^{25}$. However, our study did not reveal any differences between Syrian and Turkish babies in terms of preterm delivery, SGA, congenital abnormalities, $1^{\text {st }}$ and $5^{\text {th }}$ minute Apgar scores, RDS, TTN, treatment for jaundice, feeding problems, sepsis, duration of hospitalization, or mortality.

Although the rate of PROM was higher in Syrian women, it did not affect rates of neonatal sepsis. Erenel et al. ${ }^{26}$ reported that the rates of preterm birth, low birth weight, and fetal anomalies were similar in Syrian refugees and control groups. Similarly, Güngör et al. ${ }^{15}$ showed that Syrian and Turkish infants had similar birth weights, $1^{\text {st }}$ and $5^{\text {th }}$ minute Apgar scores, hospitalization rates, and fetal anomalies.

\section{LIMITATIONS}

This was a retrospective study based on medical record data. Therefore, patients from outside centers with incomplete medical records could not be included. Also, communication problems impaired the ability to gather some information about previous pregnancies, cesarean sections, systemic diseases, and antenatal follow-up from Syrian mothers.

\section{CONCLUSION}

Although previous studies have reported poor perinatal outcomes for Syrian immigrants in Turkey, it is seen that these results are better in recent studies and our results indicated that neonatal morbidity rates between Syrian migrant mothers and native Turkish mothers were similar. The increased duration of residence of Syrian refugees in Turkey and the successful implementation of free healthcare for Syrian refugees by the Turkish government likely contributed to this improvement.

\section{REFERENCES}

1. Kirişci K. Turkey: A transformation from emigration to Immigration. Migration Information Source (Online Journal-2003), https://www.migrationpolicy.org/article/turkey-transformation-emigration-immigration. Accessed 20 September 2019.

2. United Nations Refugee Agency. Inter-agency Information Sharing Portal http://data.unhcr.org/syrianrefugees conutry. Accessed 20 September 2019.

3. Gibson-Helm M, Teede H, Block A, et al. Maternal health and pregnancy outcomes among women of refugee background from African countries: a retrospective, observational study in Australia. BMC Pregnancy Childbirth. 2014;14:392. [CrossRef]

4. Cacciani L, Asole S, Polo A, et al. Perinatal outcomes among immigrant mothers over two periods in a region of central Italy. BMC Public Health. 2011;11:294. [CrossRef]

5. Vik ES, Aasheim V, Schytt E, Small R, Moster D, Nilsen RM. Stillbirth in relation to maternal country of birth and other migration related factors: a population-based study in Norway. BMC Pregnancy Childbirth. 2019;19:5. [CrossRef]

6. Gagnon AJ, McDermott S, Rigol-Chachamovich J, et al. ROAM Collaboration. International migration and gestational diabetes mellitus: a systematic review of the literature and meta-analysis. Paediatr Perinat Epidemiol. 2011;25:575-92. [CrossRef]

7. Merry L, Small R, Blondel B, Gagnon AJ. International migration and caesarean birth: a systematic review and meta-analysis. BMC Pregnancy Childbirth. 2013;13:27. [CrossRef]

8. Partridge S, Balayla J, Holcroft CA, Abenhaim HA. Inadequate prenatal care utilization and risks of infant mortality and poor birth outcome: a retrospective analysis of 28,729,765 U.S. deliveries over 8 years. Am J Perinatol. 2012;29:787-93. [CrossRef]

9. Abu Hamad Kh, Abed Y, Abu Hamad B. Risk factors associated with preterm birth in the Gaza Strip: hospital-based case-control study. East Mediterr Health J. 2007;13:1132-41. [CrossRef]

10. Jamieson DJ, Meikle SF, Hillis SD, Mtsuko D, Mawji S, Duerr A. An evaluation of poor pregnancy outcomes among 
Burundian refugees in Tanzania. JAMA. 2000;283:397402. [CrossRef]

11. Cantürk FK, Dağlı SS, Cantürk M. Kırşehir İlindeki Suriyeli Mültecilerin Perinatal Sonuçlarının Değerlendirilmesi. Ahi Evran Med. J. 2019;1:6-11.

12. Demirci H, Yildirim Topak N, Ocakoglu G, Karakulak Gomleksiz M, Ustunyurt E, Ulku Turker A. Birth characteristics of Syrian refugees and Turkish citizens in Turkey in 2015. Int J Gynaecol Obstet. 2017;137:63-6. [CrossRef]

13. Jolly MC, Sebire N, Harris J, Robinson S, Regan L. Obstetric risks of pregnancy in women less than 18 years old. Obstet Gynecol. 2000;96:962-6. [CrossRef]

14. Rosengard C, Phipps MG, Adler NE, Ellen JM. Adolescent pregnancy intentions and pregnancy outcomes: a longitudinal examination. J Adolesc Health. 2004;35:453-61. [CrossRef]

15. Güngör ES, Seval O, İlhan G, Verit FF. Do Syrian refugees have increased risk for worser pregnancy outcomes? Results of a tertiary center in İstanbul. Turk J Obstet Gynecol. 2018;15:23-27. [CrossRef]

16. Alnuaimi K, Kassab M, Ali R, Mohammad K, Shattnawi K. Pregnancy outcomes among Syrian refugee and Jordanian women: a comparative study. Int Nurs Rev. 2017;64:584-592. [CrossRef]

17. Huster KM, Patterson N, Schilperoord M, Spiegel P. Cesarean sections among Syrian refugees in Lebanon from december 2012/january 2013 to june 2013: probable causes and recommendations. Yale J Biol Med. 2014;87:269-88.

18. Appropriate technology for birth. Lancet. 1985;2(8452):436-7. [CrossRef]

19. Sorbye IK, Daltveit AK, Sundby J, Stoltenberg C, Vangen
S. Caesarean section by immigrants' length of residence in Norway: a population-based study. Eur J Public Health. 2015;25:78-84. [CrossRef]

20. Kandasamy T, Cherniak R, Shah R, Yudin MH, Spitzer R. Obstetric risks and outcomes of refugee women at a single centre in Toronto. J Obstet Gynaecol Can. 2014;36:296302. [CrossRef]

21. Wanigaratne S, Cole DC, Bassil K, Hyman I, Moineddin R, Urquia ML. The influence of refugee status and secondary migration on preterm birth. J Epidemiol Community Health. 2016;70:622-8. [CrossRef]

22. Salvador S, Bertozzi S, Londero AP, Driul L, Da Riol R, Marchesoni D. Outcome of pregnancy for immigrant women: a retrospective study. Minerva Ginecol. 2010;62:277-85.

23. Rizzo N, Ciardelli V, Gandolfi Colleoni G, et al. Delivery and immigration: the experience of an Italian hospital. Eur J Obstet Gynecol Reprod Biol. 2004;116(2):170-2. [CrossRef]

24. Small R, Gagnon A, Gissler M, et al. Somali women and their pregnancy outcomes postmigration: data from six receiving countries. BJOG. 2008;115:1630-40. [CrossRef]

25. Agudelo-Suárez AA, Ronda-Pérez E, Gil-González D, González-Zapata LI, Regidor E. Relationship in Spain of the length of the gestation and the birth weight with mother's nationality during the period 2001-2005. Rev Esp Salud Publica. 2009;83:331-7. [CrossRef]

26. Erenel H, Aydogan Mathyk B, Sal V, Ayhan I, Karatas S, Koc Bebek A. Clinical characteristics and pregnancy outcomes of Syrian refugees: a case-control study in a tertiary care hospital in Istanbul, Turkey. Arch Gynecol Obstet. 2017;295:45-50. [CrossRef] 